\title{
Posterior reversible encephalopathy syndrome: a case report
}

\section{Kumkum Srivastava, Parul Sinha, Shalini Dwivedi*}

Department of Obstetrics \& Gynecology, Era’s Lucknow Medical College, Lucknow, Uttar Pradesh, India

Received: 13 October 2014

Accepted: 1 November 2014

\author{
*Correspondence: \\ Dr. Shalini Dwivedi, \\ E-mail: pushpamd@yahoo.com
}

Copyright: (C) the author(s), publisher and licensee Medip Academy. This is an open-access article distributed under the terms of the Creative Commons Attribution Non-Commercial License, which permits unrestricted non-commercial use, distribution, and reproduction in any medium, provided the original work is properly cited.

\begin{abstract}
Posterior Reversible Encephalopathy Syndrome (PRES) is a clinic radiological entity, characterized by variable associations of seizure activity, consciousness impairment, headache, visual abnormalities, nausea and vomiting and focal neurological signs. The global incidence of PRES is not known. It can develop in association with conditions like exposure to toxic agents, hypertension, infection and eclampsia was present in $7 \%$. So, here I am presenting a case of our patient of 22 years primigravida, who presented with ante partum eclampsia at 28 weeks of gestation and delivered vaginally by induction of labor. Post-delivery she developed PRES which was diagnosed by MRI.
\end{abstract}

Keywords: Posterior reversible encephalopathy syndrome, Eclampsia, Preeclampsia

\section{INTRODUCTION}

Posterior reversible encephalopathy syndrome is a clinicoradiological entity that was well described by Henley et al. ${ }^{1}$ This condition has been designated by a variety of names (reversible posterior leukoencephalopathy syndrome, reversible posterior cerebral edema syndrome and reversible occipital parietal encephalopathy). PRES is characterized by variable associations of seizure activity, consciousness impairment, headache, visual abnormalities, nausea/vomiting, and focal neurological signs. Recognition of PRES has evolved with increasing availability of Magnetic Resonance Imaging (MRI). The global incidence of PRES is unknown. PRES can develop in association with a vast array of conditions like exposure to toxic agents, ${ }^{2}$ hypertension, infection and septic shock. Preeclampsia and eclampsia were present in $7 \%,{ }^{3}$ autoimmune disease. So in our case, the patient had antepartum eclampsia.

\section{CASE REPORT}

A 22 year primigravida belonging to low socioeconomic status presented in obstetric emergency of Era's Lucknow medical college on 14 January 2014 at 28 weeks pregnancy with antepartum eclampsia. She had headache for 2 days and 4 episodes of tonic clonic seizures. There was no history of any chronic illness and no family history of similar complaints. On admission the patient was not oriented to time, place and person. Her pulse rate was $101 / \mathrm{min}$, respiratory rate was $22 / \mathrm{min}$, blood pressure was $170 / 120 \mathrm{mmHg}$, chest was clear; S1 \& S2 were heard normally. Pallor and edema were present and her reflexes were exaggerated. Fundus examination showed no signs suggestive of hypertensive changes. On per abdomen examination uterus was $26-28$ weeks size, lie was longitudinal, cephalic presentation, two mild contractions lasting for 20 seconds were present and fetal heart rate was 140 beats per minute. On per vaginum examination, os was $1.5 \mathrm{~cm}$ dilated; cervix was soft and early effaced. $\mathrm{Hb}$ was $12 \mathrm{~g} \%$, blood group was B positive. Viral markers were negative. TLC was 16000 cumm, S. creatinine was $1.04 \mathrm{mg} \%$, liver enzymes were markedly raised, Uric acid was $8 \mathrm{gm} \%$ and albumin was $3.2 \mathrm{mg} / \mathrm{dl}$. Magnesium sulphate was given by Pritchard's regimen and tablet labetalol started at a dose of $100 \mathrm{mg}$ twice daily. Labor was augmented by misoprostol and she delivered per vaginally a live male baby of $1.1 \mathrm{~kg}$ who was admitted in NICU. Post-delivery the patient was 
disoriented and irritable, had delayed response, scaring behavior, was very uncooperative in following the treatment. Her MRI brain was advised, which revealed bilateral symmetrical subtle T2 hyper intensities involving frontal, occipital and left parietal region which showed post contrast enhancement. No evidence of sinus venous thrombosis and the presentation was suggestive of PRES.

\section{DISCUSSION}

PRES is a group of clinical disorders in which patient presents with combination of the following signs and symptoms, alteration in neural state, headache, occasional focal neurological signs, visual loss, seizure and rarely coma. Hypertensive encephalopathy, renal failure, vasculitis, immunosuppressive treatment and eclampsia have been reported to be the major causes of this syndrome. PRES can also occur after chemotherapy with cytarabine, cisplatin, benzixumab and kinase inhibitors. Computed tomography scan shows vasogenic edema predominantly of the perioccipital subcortical white matter, but involvement of the brain stem, cerebellum, frontal lobes and basal ganglia are possible as well. Recent advances in magnetic resonance imaging and availability of fluid attenuated inversion recovery (FLAIR) sequences, diffusion-weighted imaging, and Apparent Diffusion Coefficient (ADC) mapping have shown that edema occurs in both gray and white matter. The association of PRES with toxemia of pregnancy is well established. ${ }^{4,5}$ Pathophysiology of PRES remains controversial. The two main hypotheses contradict each other. ${ }^{6}$ One involves impaired cerebral auto regulation responsible for an increase in cerebral hypo perfusion. This hypo perfusion hypothesis may be most relevant to cases of PRES associated with cytotoxic therapy. Under both hypotheses, the result of the cerebral blood perfusion abnormalities is blood brain barrier dysfunction with cerebral vasogenic edema. .Diagnosis by neuro imaging such as catheter angiogram MRA and 3D time of flight Tc 99m SPECT and rCBV can be utilized. Clinical suspicion with attention to predisposing factors along with neuroimaging evidence of cerebral edema are sufficient for diagnosis. ${ }^{7}$ General measures in patients with PRES requires the symptomatic measures usually taken in the ICU. Upper airway protection should be evaluated continuously in patients with marked consciousness impairment or seizure activity. Control of hypertensive emergency, if present, is an important part of the symptomatic management. The aim is not to normalize the blood pressure but rather to decrease the MAP by $20-25 \%$ within the first 2 hours and to bring the blood pressure down to $160 / 100 \mathrm{mmHg}$ within the first 6 hours. ${ }^{8}$

Funding: No funding sources

Conflict of interest: None declared

Ethical approval: Not required

\section{REFERENCES}

1. Bartynski WS. PRES part 1: fundamental imaging and clinical features. AJNR Am J Neuroradiol. 2008;29:1036-42.

2. Lee VH, Wijdicks EF, Manno EM, Rabin Stein AA. Clinical spectrum of PRES. Arch Neurol. 2008;65:205-10.

3. McKinney AM, Short J, Truvit CL, McKinney ZJ, Kozak OS, SantaCruz KS, et al. PRES: incidence of atypical regions of involvement and imaging findings. AJR Am J Roentgenol. 2007;189:904-12.

4. Koch S, Rabinstein A, Falcon S, Forteza A. Diffusion-weighted imaging shows cytotoxic and vasogenic edema in eclampsia. AJNR Am J Neuroradiol. 2001;22:1068-70.

5. Schaefer PW, Buonanno FS, Gonzalez RG, Schwamm LH. Diffusion-weighted imaging discriminates between cytotoxic and vasogenic edema in a patient with eclampsia. Stroke. 1997;28:1082-5.

6. (Dekker GA, Sibai BM. Etiology and pathogenesis of preeclampsia: current concepts. Am J Obstet Gynecol. 1998;179:1359-75.

7. Bartynski WS. PRES, part 2: controversies surrounding pathophysiology of vasogenic edema. AJNR Am J Neuroradiol. 2008;29:1043-9.

8. Moratella MB. PRES. Emergency Med J. 2010;27:547.

DOI: $10.5455 / 2320-1770 . i j r \operatorname{cog} 20141260$

Cite this article as: Srivastava K, Sinha P, Dwivedi S. Posterior reversible encephalopathy syndrome: a case report. Int J Reprod Contracept Obstet Gynecol 2014;3:1155-6. 